\title{
Relações Estado-Sociedade no Brasil: Representações para Uso de Reformadores*
}

\author{
Frederico Lustosa da Costa
}

\section{INTRODUÇÃO}

$\mathrm{O}$ $s$ grandes intérpretes da realidade brasileira têm salientado que as raízes de nosso atraso, subdesenvolvimento, dependência, modernização periférica ou inserção pouco competitiva no mundo globalizado estão plantadas em nossa formação histórica, gerando uma série de determinantes que condicionam o sistema político, o Estado e suas relações com a sociedade e a economia. Essas peculiaridades constituem modos de ser, proceder ou pensar que caracterizam nossas instituições, relações sociais e representações do mundo social e político. Patrimonialismo, mandonismo, personalismo, formalismo, clientelismo, cartorialismo, centralismo e autoritarismo são exemplos das "deformações" ou "patologias" utilizadas para descrever aspectos de nossa realidade, particularmente do Estado, do governo e da administração pública, que se constituiriam nas causas da pouca efetividade da ação governamental. Alguns desses "problemas" encontram variantes conceituais mais recentes em categorias como democracia delegativa (O’Donnell, 1991), mundo estatofóbico e hobbesiano (Santos, 1993), cultura paroquial (Carvalho, 1996), anéis burocráticos

\footnotetext{
* Este artigo nasceu de um trabalho mais amplo, intitulado Reforma Gerencial do Estado no Brasil - Condicionantes, Estratégias e Resultados, originalmente apresentado como tese de doutoramento junto ao Instituto Superior de Ciências do Trabalho e da Empresa (ISCTE), em Lisboa, em 21 de junho de 2007.
}

DADOS - Revista de Ciências Sociais, Rio de Janeiro, Vol. 52, nํ1, 2009, pp. 161 a 199. 
(Cardoso, 1975), estadania (Carvalho, 1987) e neocorporativismo, utilizadas para descrever a apropriação do público pelo privado, o compadrio, a vassalagem, a barganha, a fisiologia, o "bacharelismo", a centralização e a precariedade da democracia.

A persistência com que essas categorias continuam a ser resgatadas, criticadas e atualizadas dá conta de sua importância para a compreensão do país e para a construção da imagem que os brasileiros fazem de si mesmos. Elas revelam apreciações sobre a realidade nacional que informam não só os julgamentos irrefletidos e as atitudes cotidianas mas também as análises científicas e as políticas públicas. A extensa produção acadêmica sobre esses temas não permitiu chegar a conclusões definitivas sobre a natureza, extensão, duração, cristalização ou superação dos fenômenos que descrevem. Não importa. Ainda que esses conceitos não constituíssem elaborações nascidas de fatos e atos verificáveis, eles têm existência estabelecida no mundo das representações, acabando por produzir impactos sobre as práticas sociais e as instituições que as regulam. São imagens simbólicas (Sfez, 1988) que veiculam e atualizam representações ${ }^{1}$. Convém, portanto, mantê-los na agenda, pelo menos até que a roda da história faça girar o círculo (não sequencial) das instituições, práticas e representações.

A permanência dessas concepções não quer dizer que a realidade nacional seja imutável. O Brasil, como, de resto, o mundo inteiro, tem sofrido profundas transformações econômicas, sociais, políticas e mesmo culturais, sobretudo nos últimos 75 anos. Durante o século XX, foi o país que mais cresceu em todo o globo. Passou de uma economia primário-exportadora a um grande parque industrial; de uma sociedade rural a um conglomerado de metrópoles densamente povoadas; do particularismo local à cultura de massas. O país incorporou a suas instituições e práticas sociais, sobretudo nas esferas do Estado e do mercado, elementos da racionalidade prevalente nas economias centrais. $\mathrm{O}$ Brasil modernizou-se.

Alguns desses intérpretes veem nas manifestações que esses conceitos expressam justamente o modo pelo qual a sociedade brasileira incorporou os valores da modernidade. Essa modernização, ainda que seletiva, não exclui a permanência de formas particulares de acomodação de valores e instituições modernas à ambiência tropical sem que a maior parte de suas interpretações deva ser jogada na vala comum da sociologia da inautenticidade, quer dizer, que atesta a inautenticidade 
do esforço de modernização brasileiro, segundo a crítica de Souza (2000). Traços importantes do processo brasileiro que configuram um percurso particular de modernização não constituem singularidades. Estão presentes em inúmeros países latino-americanos e até em alguns países mediterrâneos, para além da Península Ibérica. Como reitera DaMatta (1980), e como foi possível identificar em um dos primeiros estudos sistemáticos sobre "o jeitinho brasileiro" (Vieira, Lustosa da Costa e Barbosa, 1982), o que é singular entre nós é o anseio de diferenciação, o desejo (ainda que diversamente motivado) dessa singularidade e a valorização positiva de alguns de seus aspectos - cordialidade, estabilidade, lealdade, esperteza, flexibilidade etc.

Como a maioria das disfunções põe o Estado no centro do processo, seja como agente, seja como paciente ou cenário, deve-se admitir que, quando se cogita realizar reformas institucionais (no Estado, para o Estado ou com o Estado), essas características devem ser devidamente consideradas, pois "as circunstâncias políticas, o contexto social e cultural e a pluralidade dos poderes e grupos de influência em que a administração está envolvida não permitem a implementação de tiposideais isolados das realidades e do meio envolvente" (Mozzicafreddo, 2001:19). Como lembra Claus Offe,

é bem possível que o desnível entre o modo de operação interna e as exigências funcionais impostas do exterior à administração do Estado não se deva à estrutura de uma burocracia retrógrada, e sim à estrutura de um meio sócio-econômico que [...] fixa a administração estatal em um certo modo de operação [...]. É óbvio que um desnível desse gênero entre o esquema normativo da administração e as exigências funcionais externas não poderia ser superado através de uma reforma administrativa, mas somente através de uma "reforma" daquelas estruturas do meio que provocam a contradição entre estrutura administrativa e capacidade de desempenho (1984:219; ênfase no original).

Estamos, assim, diante de uma série de aspectos diversificados, complexos e inter-relacionados da realidade brasileira que condicionam o funcionamento do Estado e a ação e o desenvolvimento da administração pública, e continuam a desafiar os cientistas sociais. As proclamadas "mazelas" brasileiras têm sido examinadas ora como "dados da realidade" ou "parte da nossa cultura", ora como condicionantes estruturais, ora, ainda, como resíduos do passado colonial e das estruturas oligárquicas que estão desaparecendo "naturalmente". 
Vistos como traços culturais, esses atributos podem ter dois tipos de tratamento, como variável independente ou como variável dependente, de acordo com uma visão mais ou menos instrumentalizada que se tenha da cultura (Harrison e Huntington, 2002:13). Se for tratada como variável independente, a cultura - ou a cultura política - ajuda a entender e a explicar a organização e o funcionamento do Estado, a conformação do sistema político e o padrão de democracia (DaMatta, 1980). Se a cultura for definida como variável dependente, trata-se de identificar os obstáculos culturais à modernização do Estado e as formas de ação política que permitem removê-los (Beltrão, 1984).

Analisados como determinantes de disfunções do Estado, os fatores estruturais do contexto brasileiro passam a requerer profundas transformações econômicas, sociais e políticas para que possam produzir efeitos sobre a ação estatal (Santos, 1993; Motta, 1987). A modernização do Estado seria, assim, consequência de mudanças sociais de maior envergadura. Considerando, entretanto, que essas transformações dependem, em grande medida, da própria ação estatal, a reforma do Estado poderia ser caracterizada como a mãe de todas as reformas. Em um ou em outro caso, a reforma do Estado - ou a grande transformação - passa a constituir um empreendimento de tal magnitude que se torna difícil de ser concretizado.

Percebidos apenas como sobrevivências do passado, os problemas brasileiros estão fadados a desaparecer por causa do processo natural de evolução da sociedade (Souza, 2000) em sua marcha progressiva para o racional. Nesse sentido, a reforma do Estado pode contribuir para acelerar esse processo (Bresser-Pereira, 2001).

As diversas atitudes intelectuais podem aparecer de forma isolada ou combinada e informar diferentes estratégias de reforma, mas não logram estabelecer relações diretas entre constatações e propostas de mudança. Em todos os casos, põem em primeiro plano o caráter normativo da discussão sobre reforma do Estado.

Aqui, procede-se, mais uma vez, ao exame de três das características mais recorrentes nas interpretações do Brasil - o patrimonialismo, o mandonismo e o personalismo (ou pessoalidade) -, evocando-se outras disfunções a elas relacionadas - o clientelismo e o autoritarismo e seus efeitos sobre o exercício dos direitos de cidadania. Essas características foram escolhidas em função da frequência de seu aparecimento na literatura e dos alegados impactos mais diretos, que essa mesma 
literatura indica, sobre o funcionamento do aparelho do Estado, sobretudo em suas relações com a sociedade.

Tomadas separadamente, em conjunto ou combinadas de diferentes maneiras, essas linhas interpretativas traçam o retrato de um Brasil arcaico, desenhado a partir da perspectiva histórica, profundamente enraizado no terreno dos bolsões de pobreza, das áreas rurais e das regiões mais profundas da alma brasileira. Esse retrato se contraporia a outro, pintado com as cores da modernidade, a partir de matizes contemporâneos - instituições e regras, dados eleitorais e estatísticas judiciais (Santos, 1993), surveys sobre cidadania e justiça (Carvalho et alii, 1998), revelando um país caracterizado por desprivatização do Estado, moral individualista, universalismo de procedimentos, participação política, ativismo social e espaço público ampliado.

A referência a "retratos" sublinha o caráter de representações coletivas dessas categorias. Não se trata de retomar a teoria do dualismo, aludindo à existência de dois Brasis que se justapõem. Essa tese, muito difundida desde os anos 1930, descreve o país a partir de uma percepção dicotomizada da realidade, contrapondo conjuntos de atributos negativos a grupos de características positivas. Do lado arcaico, o Brasil pobre, predominantemente rural, oligárquico, clientelista. Do lado moderno, o Brasil urbano, industrializado, democrático, plural, competitivo. Tanto em um quanto em outro plano, o país é um só. Forma um sistema de complementaridades em que uma parte se nutre da outra, no qual o jogo de interações vai articulando a reprodução e a mudança sociais. A dualidade é uma constatação, não uma explicação; "deve ser concebida como 'união dialética de contrários' e não como justaposição mecânica de sociedades distintas, como supõe a maioria dos estudos sobre a diversidade histórico-social no Brasil" (Ramos, 1983:422).

Esta análise permite caracterizar esses fenômenos como estrutura e função, indicar sua influência sobre práticas sociais, políticas e administrativas e avaliar seu impacto sobre o funcionamento do Estado e suas estratégias de reforma.

\section{PATRIMONIALISMO}

O tema do patrimonialismo se inscreveu na tradição do pensamento social brasileiro como a base de uma das interpretações clássicas da formação do país. Mostrado como uma das principais heranças da administração colonial, aos brasileiros parece até surpreendente que não 
seja recorrentemente apontado, nas ciências sociais lusas, como matriz do destino da civilização portuguesa. Como se explica que o patrimonialismo esteja na raiz das disfunções do Estado brasileiro e não seja visto como a causa principal da estagnação do Estado português?

Muito do sucesso da tese do patrimonialismo se deve à gradativa e crescente aceitação da obra clássica de Raymundo Faoro, Os Donos do Poder, publicada originalmente em 1957, ampliada e totalmente refundida em 1975. O autor tinha o ambicioso propósito de "abarcar, num lance geral, a complexa, ampla e contraditória realidade histórica", em um "longo período, que vai do Mestre de Avis a Getúlio Vargas", valorizando "as raízes portuguesas de nossa formação política, [...] desprezadas em favor do passado antropológico e esquecidas pela influência de correntes ideológicas, originárias da França, da Inglaterra e dos Estados Unidos" (Faoro, 2001:14). Pretendia, assim, inaugurar uma interpretação que se contrapusesse ou, pelo menos, se equiparasse às de Gilberto Freyre e Sérgio Buarque de Holanda, e que não se enquadrasse na moldura estreita do marxismo ou mesmo de outras sociologias europeias ou anglo-saxônicas.

É claro que um trabalho que adota o patrimonialismo, o estamento e o feudalismo como conceitos principais não pode deixar de ser tributário da herança intelectual de Weber. Com efeito, foi Weber (1994) quem, ao descrever as três formas de dominação legítima - carismáti$\mathrm{ca}$, tradicional e racional-legal -, traçou um amplo panorama dos tipos ideais de sociedade tradicional, pois a dominação tradicional e a formação social que lhe é correspondente se caracterizam pela prevalência de um sistema de autoridade cujo fundamento maior é a tradição, o "ontem eterno" que santifica os antigos costumes e alimenta o conformismo - assim é porque sempre foi. Afirma-se, nesse sistema, a vontade do senhor, cujos limites são fixados pela própria tradição, ou seja, as normas válidas desde sempre. Em torno do senhor (ou do príncipe), gravita o "quadro administrativo" - os dependentes pessoais ou parentes, os amigos e os fiéis -, distribuindo-se o poder de mando de acordo com sua discrição.

O conceito de patrimonialismo aparece, na sociologia weberiana, no contexto da dominação tradicional, ora como sinônimo, ora como um tipo específico, ao lado do feudalismo. Assim, a dominação tradicional pode ser do tipo patrimonial ou feudal. Já o patrimonialismo poderia ser de dois tipos - patriarcal (ou sultanista) e estamental. As duas dis- 
tinções colocam em primeiro plano o tipo de relação que se estabelece entre o senhor e seus servidores, determinando duas formas de administração.

Na estrutura patriarcal, os servidores mantêm uma relação de dependência pessoal com o senhor, não tendo direitos sobre os cargos nem honra estamental; ou são propriedades suas (escravos, servos e eunucos); ou são eleitos pela afeição (favoritos, plebeus). Nessa situação de dependência, predomina o arbítrio, contra o qual não há nenhuma garantia ou proteção. A essa forma particular de despotismo Weber classifica de sultanato.

A estrutura estamental caracteriza-se pela relativa independência dos servidores com relação ao senhor. Eles são investidos em seus cargos por privilégio ou concessão, conquistando um direito em virtude de um negócio jurídico e deles não podem ser despojados. A administração é exercida por conta própria dentro de uma determinada jurisdição ou competência.

O feudalismo possui, ao mesmo tempo, elementos típicos de relações patrimoniais e extrapatrimoniais - o despotismo patriarcal, com a devoção pessoal e o culto à fidelidade, e a estipulação contratual de direitos e deveres.

Tomado como categoria principal, equivalente à dominação tradicional, ou como categoria secundária, correspondente a uma forma particular de tradicionalismo, o patrimonialismo weberiano compreende uma ampla série de variações que têm em comum a propriedade da terra como fonte de poder, a tradição como fonte de legitimidade e o quadro administrativo de "servidores" como agentes da dominação.

Já o conceito de estrutura estamental é menos flexível. Caso particular de patrimonialismo, ou configuração do feudalismo, o estamento tem esse quadro como um conjunto de pessoas independentes, investidas em seus cargos por privilégio ou concessão do senhor, ou em virtude de contrato de compra, penhora ou arrendamento que lhes confere "direito e estabilidade":

Sua administração, ainda que limitada, é autocéfala e autônoma, exercendo-se por conta própria e não por conta do senhor. [...] O poder senhorial acha-se, pois, repartido entre o senhor e o quadro administrativo com título de propriedade e de privilégio, e esta divisão de poderes 
estamental imprime um caráter altamente estereotipado ao tipo de administração (Weber, 1994:132).

É na utilização da categoria de patrimonialismo estamental que Faoro se afasta de Weber e desenvolve sua própria teorização a partir da experiência histórica de constituição, consolidação e cristalização da monarquia portuguesa. É a proeminência da figura do rei proprietário, lavrador e comerciante que dá singularidade ao caso de Portugal, em uma Europa onde predominava o feudalismo.

Ao casar-se com Henrique de Borgonha, Tereza, filha de Afonso VI, rei de Leão e Castela, recebeu como dote paterno o Condado Portucalense, retomado dos mouros e convertido em reino por seu filho Afonso Henrique em 1139. Foi pela espada que o reino se formou, expandindo-se em direção ao sul pela reconquista dos vastos territórios abandonados pelos sarracenos. Não tendo titularidade, essas terras passam ao domínio particular do rei, que se torna, além de senhor das armas, o maior proprietário do novo reino, cujo patrimônio em muito supera o do clero e o da nobreza. A Revolução de Avis vem consolidar o poder monárquico, reduzindo a influência senhorial, com a criação dos concelhos - traço de união entre o rei e "o povo" - e o fortalecimento da burguesia comercial. As funções públicas estavam totalmente separadas da propriedade:

A concessão de senhorio ou de uma vila, filha da liberalidade do rei, não importava na atribuição de poder público, salvo em medida limitada. [...] Os cargos eram, dentro de tal sistema, dependentes do príncipe, de sua riqueza e de seus poderes. [...] O rei, quando precisava do serviço militar da nobreza territorial, pagava-a, como se paga um funcionário (Faoro, 2001:20).

Os concelhos, com suas contribuições, também concorriam para aumentar a renda do príncipe, oriunda de seu patrimônio fundiário. Além dos forais, eram inúmeras as fontes de renda - multas, direitos sobre cargos, réditos, jantar ou colheita, e outras formas de gravar as atividades da agricultura, do comércio e da indústria - sugadas pelo trabalho incansável dos mordomos, sob a chefia do almoxarife, a serviço da Casa Real, sendo indistinta a riqueza privada da pública (ibidem:22). O rei era senhor de tudo ou, pelo menos, um "sócio" com quem todos deviam repartir seus ganhos. 
Nesse novo sistema monárquico, não há a presença de uma camada de senhores autônomos entre o rei e o vassalo, unidos, uns e outros, por vínculos contratuais que possam limitar a autoridade do soberano, ou seja, não há traços do feudalismo. Portugal passou do mercantilismo estatal ao capitalismo politicamente orientado. Segundo Faoro, "o Estado torna-se uma empresa do príncipe, que intervém em tudo, empresário audacioso, exposto a muitos riscos por amor à riqueza e à glória: empresa de paz e empresa de guerra" (ibidem:40).

Mesmo no patrimonialismo português, o rei não pode governar sozinho. Sem contar com o concurso da nobreza territorial, forma um quadro administrativo de servidores dotados de saber jurídico e honra estamental. São os doutores, os letrados do estamento, espécie de nobreza funcionária, que, em nome do rei, exercem dominação. O estamento, comunidade de poder que se projeta de cima para baixo, "manda, governa, dirige, orienta, determinando não apenas formalmente o curso da economia e as expressões da sociedade, sociedade tolhida, impedida, amordaçada" (ibidem:63). Mas esse grupo não constitui uma classe social inorgânica, gerada na mera comunidade de interesses - é marcado pela desigualdade social e reúne indivíduos de todas as classes -, tampouco se degrada em burocracia ou se reduz a uma comunidade de dependentes. Pouco a pouco, separa os negócios sob sua jurisdição da propriedade particular do rei e apropria-se de privilégios e favores como apanágios da honra estamental. Mantém com o soberano uma relação de codependência, servindo com honra e lealdade, com o fazer que obra e enriquece e o saber que ilustra e legitima. Na sociologia de Faoro, o estamento deixa de ser uma categoria coletiva e plural (estamentos), designando diversos grupos sociais, para afirmar-se como sinônimo de categoria social dominante.

Seria desnecessário seguir o percurso de Faoro por mais de oito séculos de história, em uma "viagem redonda", para mostrar como o patrimonialismo se cristalizou como moldura social e política da vida brasileira, mantendo em primeiro plano, autônomo, sobranceiro, tutelador e sufocante, o estamento político. A história é quase imóvel e o argumento, reiterativo. Da Coroa portuguesa à administração colonial, do Reino Unido ao Império brasileiro, da Independência à República, da política dos governadores da República Velha ao Estado Novo de Vargas, mantiveram-se intactos o regime patrimonialista e o poder do estamento. 
Escrita em linguagem culta e fartamente documentada, a obra de Faoro tornou-se um clássico, reverenciada por várias gerações de cientistas sociais. É, ao mesmo tempo, um objeto de erudição e "uma coisa pensada", confundindo as instigantes categorias antinômicas propostas por Hannah Arendt (1987). Influenciou inúmeros trabalhos, alguns dos quais também se converteram em clássicos, como Bases do Autoritarismo Brasileiro, de Simon Schwartzman (1988), A Querela do Estatismo, de Antonio Paim (1978), e Carnavais, Malandros e Heróis, de Roberto DaMatta (1980). Não está, porém, imune a críticas, algumas bastante acerbas.

O primeiro reparo que se faz a Faoro está relacionado ao próprio uso das categorias weberianas. Como expresso anteriormente, a noção de patrimonialismo estamental estaria bastante próxima do conceito de feudalismo. Quer dizer, o estamento se afirma onde há uma relação contratual que lhe assegura autonomia. A designação do servidor, ditada por escolha pessoal, seja por mérito, seja por afeição, é própria do patrimonialismo patriarcal, ou sultanato (Campante, 2003:158). Como, segundo Faoro, o feudalismo, com a dominação de uma nobreza territorial autônoma, em relação contratual com o soberano, não existiu em Portugal nem no Brasil, o estamento, português e brasileiro, não cabe na extensa e flexível taxonomia weberiana. Seria de outra ordem, constituído e notabilizado por obra e graça do rei.

A fidelidade à obra de Weber não acrescentaria méritos ao trabalho de Faoro. O problema é de outra ordem. Está relacionado à transplantação e à utilização adequada de conceitos. Ao rejeitar - muito apropriadamente, aliás - a hipótese do feudalismo português e afirmar a proeminência do estamento político no patrimonialismo luso-brasileiro, o autor coloca em causa uma das bases de seu próprio modelo - a concentração de poder. Faoro não se cansa de repetir que o patrimonialismo ibero-americano é, por natureza, centralizador. Trata-se de um sistema hierarquizado que exerce uma força centrípeta sobre todos os domínios do Império português, trazendo-os para próximo do rei e do estamento político que lhe serve as decisões e os recursos. No feudalismo (estamental), há uma "tensão" entre o rei e a nobreza territorial que se resolve pela via contratual. No sultanato, o servidor tem poderes limitados e é um agente do soberano, muitas vezes vigiado por outro servidor local ou itinerante. No patrimonialismo estamental de Faoro, não há lugar para a descentralização, o que poderia caracterizar uma ordem feudal. 
Assim, para manter a solidez dos argumentos patrimonialistas (e centralizadores), Faoro acaba por negligenciar a importância do mandonismo rural na vida política brasileira. Os grandes proprietários de terras, exercendo, longe do poder institucionalizado do Estado, a autoridade real e simbólica, constituíam, em determinado momento, uma classe senhorial dotada de poder econômico e de consciência de classe (para não dizer honra estamental).

A terceira crítica à obra de Faoro diz respeito ao imobilismo histórico que o emprego da teoria do patrimonialismo estamental determina. Em oitocentos anos de história, o patrimonialismo fez uma viagem redonda, fechado sobre si mesmo, infenso às transformações econômicas, revoluções políticas, mudanças sociais, transplantações geográficas e operações simbólicas. O estamento, "congelado", manteve-se no centro do mercantilismo estatal e do capitalismo politicamente orientado, atualizando-se para se reproduzir.

Três argumentos poderiam ser utilizados a favor de Faoro, ainda que para sustentá-los se deva sucumbir a um anacronismo ex ante factum. Em primeiro lugar, o modelo do patrimonialismo estamental poderia ser considerado uma espécie de teoria da reprodução social apoiada na prevalência do capital social como elemento instituidor da hierarquização e da ordem e motor de sua dinâmica de transformação (Bourdieu e Passeron, 1977). Em segundo lugar, Os Donos do Poder pode ser considerado um exemplo, avant la lettre, de história da longa duração, descrevendo os mecanismos de conservação e transformação das mentalidades ou representações sociais ${ }^{2}$. Por último, a teoria do patrimonialismo de Faoro anuncia, descreve e estrutura a dinâmica intrínseca que permite dar ao estamento uma capacidade adaptativa, assegurando-lhe a condução do processo de transformação econômica em interação dinâmica com o capitalismo mundial. Nesse sentido, o estamento foi moderno e modernizador, o que, de certo modo, reduz o impacto do argumento que se segue.

A quarta crítica mais comum vê na análise do patrimonialismo uma condenação à herança ibérica, que nos teria legado uma experiência histórica que "adotou do capitalismo a técnica, as máquinas, as empresas, sem aceitar-lhe a alma ansiosa de transmigrar" (Faoro, 2001:822), quer dizer, o liberalismo. Os Donos do Poder seria um libelo estatofóbico que, ao demonizar o estamento, acaba por condenar também o Estado que assenhoreou. 
Souza denuncia a teleologia do argumento, a forma esquemática como Faoro percebe o processo de desenvolvimento ocidental e acredita que seu ponto de vista

é o do liberal clássico que percebe a singularidade do capitalismo bem-sucedido e democrático segundo o modelo de uma sociedade que se constitui antes do Estado, permitindo o florescimento tanto das liberdades econômicas quanto das públicas e democráticas. Escapa a Faoro que esse caminho, longe de ser a regra, foi a exceção do desenvolvimento ocidental. Esse ponto é fundamental. É ele que irá explicar de que modo a categoria a-histórica de estamento patrimonial que o autor constrói possa transmutar-se quase que imperceptivelmente na noção pura e simples de Estado interventor (Souza, 2000:171-172).

A mera leitura do texto, entretanto, não mostra, em Faoro, tantos pendores para a louvação do liberalismo. Ao contrário, ele critica as perspectivas históricas que tomam como única referência o

capitalismo moderno, tal como decantado por Adam Smith, Marx e Weber, tratados os estilos divergentes como se fossem desvios, atalhos sombreados, revivescências deformadoras, vestígios evanescentes. [...] A sociedade capitalista aparece aos olhos deslumbrados do homem moderno como a realização acabada da história - degradadas as sociedades a fases imperfeitas, num processo dialético e não mecânico, de qualquer sorte, substituindo o fato bruto ao fato racional, que bem pode ser o fato idealizado artificialmente. No fundo, a tese da unidade da história, acelerada, sendo criada, pelo império do capitalismo (Faoro, 2001:822).

A viagem redonda de Faoro se encerra no auge da era Vargas, quando o soberano se converte em presidente populista, pai dos pobres, distribuindo benesses em um sistema político fechado e autoritário, mas sugere a continuidade do patrimonialismo nos anos subsequentes.

O que aconteceu nas décadas posteriores que justifica a permanência do tema na agenda de pesquisa das ciências sociais e, sobretudo, nas representações do Estado e do poder político?

Nos últimos sessenta anos, a partir do primeiro governo Vargas, o Brasil empreendeu um enorme esforço de modernização, inclusive de suas instituições públicas. Sob a regência do Estado, o desenvolvimento econômico baseado no processo de industrialização pela substituição de importações permitiu a superação do modelo agroexportador 
em declínio, a constituição de uma sociedade urbano-industrial, a criação das estruturas de proteção e seguridade social e a organização política pluralizada de vários segmentos sociais.

A ação estatal criou as condições para que se estabelecesse "um mercado onde os diversos agentes econômicos pudessem movimentar-se em liberdade. A esfera pública ampliou-se para criar os espaços de domínio privado" (Lustosa da Costa e Cavalcanti, 1991:89). Na medida em que constituiu um setor público dos mais equipados e eficientes do Terceiro Mundo, o Estado brasileiro tentou ser moderno e modernizador. Isso não implica aceitar a tese do patrimonialismo modernizante proposta por Paim (1978), ainda que se reconheça o caráter autoritário, centralizador e estatizante do projeto de desenvolvimento nacional do século XX, cujos resultados mais expressivos, em termos de crescimento econômico, se deram em regimes de exceção.

Conduzida pelo estamento, apesar dele, ou mesmo contra ele, a modernização brasileira se deu dentro dos marcos do domínio patrimonial e, por isso, jamais logrou minar as bases dos interesses oligárquicos e estamentais que dele se beneficiam. Prevaleceu a força da tradição legitimadora da privatização do Estado, que se manteve como principal arena da política de grupos.

Qual é o impacto da obra de Faoro na análise do patrimonialismo sobre os estudos e as propostas de reforma administrativa?

Em primeiro lugar, é preciso que se diga que a maioria dos trabalhos sobre reformas faz referência à herança ibérica e à tradição patrimonialista como obstáculos à modernização do Estado, da economia e da sociedade brasileira. Características do patrimonialismo weberiano, como "os fundamentos personalistas do poder, a falta de uma esfera pública contraposta à privada, a racionalidade subjetiva e casuística do sistema jurídico, a irracionalidade do sistema fiscal, a não-profissionalização e a tendência intrínseca à corrupção do quadro-administrativo" (Campante, 2003:161), são automaticamente relacionadas ao patrimonialismo estamental de Faoro e tomadas como causas da ineficiência da burocracia governamental. Nessa perspectiva, o patrimonialismo se manifestaria como realidade observável nas relações promíscuas entre agentes do Estado e interesses particularistas, nas formas de arregimentação de quadros e de distribuição de cargos típicas do spoil system e do nepotismo, na permanência de mecanismos de favoreci- 
mento e concessões privilegiadas e nas variadas práticas de corrupção subsistentes.

Embora não haja, na literatura brasileira, muitos estudos empíricos com dados factuais sobre essas manifestações, uma série de evidências pode ser colhida no noticiário e assim informar uma alentada agenda de pesquisa. São exemplos sempre lembrados de promiscuidade entre o público e o privado a persistência do nepotismo nos poderes Legislativo e Judiciário, o processo de privatizações no governo Fernando Henrique Cardoso, a forma de nomeação de titulares de cartório e os processos de escolha dos concessionários de canais de rádio e televisão.

Mais importante do que a realidade observável são as representações sociais que se constituem a partir da tomada de consciência da herança lusitana. Por meio da imagem construída pelo noticiário e por análises históricas ligeiras, o Estado passa a ser visto como propriedade de um grupo que tenta, a todo custo, manter privilégios e vantagens pessoais contra os interesses populares. A máquina é ineficiente, onerosa e perdulária; seus agentes, gananciosos e inescrupulosos. Muitas vezes, os donos do poder são personificados nos servidores públicos, vistos como "marajás".

Essa visão determina uma agenda negativa de reforma do Estado e culpabiliza um dos elos mais fracos na cadeia de comando do Estado patrimonial. Afinal, quem são os donos do poder? Por outro lado, seu viés estatofóbico nega o caráter estratégico e funcional da intervenção do Estado na economia brasileira durante o século XX.

A tese do patrimonialismo suscita duas atitudes intelectuais que produzem consequências em termos de política de reforma:

- O patrimonialismo está superado e, portanto, a reforma cogita corrigir disfunções da administração burocrática.

- O patrimonialismo é superável e, assim, a reforma deve agir a fim de burocratizar o Estado e punir os comportamentos desviantes - nepotismo, favoritismo, clientelismo e corrupção.

Não há quem considere que o patrimonialismo seja insuperável, mas imprecisões conceituais, já apontadas por Carvalho (1997), acabam por confundir patrimonialismo com clientelismo, corporativismo e, até mesmo, com simples corrupção, indicando a permanência do fenômeno e magnificando sua dimensão (Pinho, 1998). 
A atitude contrária, que registra o completo desaparecimento do patrimonialismo, orienta o foco para a administração burocrática (e suas distorções) e informa estratégias de flexibilização orientadas para sua superação, ensejando a possibilidade de eliminação de mecanismos de salvaguarda dos princípios do universalismo, da isonomia e da equanimidade, ainda sujeitos às vicissitudes da democracia e da cidadania no Brasil.

Finalmente, aceitar a hipótese sugerida pelo próprio Faoro, subscrita por Beltrão e mesmo por Bresser-Pereira, de que o patrimonialismo tem, além de sua dimensão institucional, uma vertente cultural, impondo-se como uma "mentalidade" presente na sociedade brasileira, não implica propor estratégias de "mudança cultural" dentro de uma concepção instrumentalizada da cultura ou da cultura política. Ao contrário, trata-se de conduzir transformações nas práticas administrativas dentro do espaço das representações sociais, quer dizer, de gerar novas possibilidades de interação das normas, práticas e representações.

\section{CORONELISMO E MANDONISMO}

Um dos temas recorrentes da sociologia política brasileira é o coronelismo. Espécie de mandonismo local, típico dos sertões nordestinos, o coronelismo é a expressão de uma realidade econômica, social e política mais ampla, encontrada, no passado, em quase todas as regiões do país. Designa o sistema de dominação exercido pelos potentados rurais.

A palavra deve sua origem ao posto mais elevado da Guarda Nacional, criada em 1831, em substituição às milícias existentes durante o período colonial. De início, os oficiais da Guarda eram eleitos, mas, a partir de 1837, os coronéis, majores e capitães passaram a ser nomeados, entregando-se esses postos aos notáveis de cada lugar, de acordo com sua posição social. Para gozarem de suas prerrogativas, os oficiais tinham de obter suas patentes pagando emolumentos e averbações. Possuíam uniformes, com as insígnias correspondentes a cada posto, que envergavam nas festas cívicas e religiosas e nas ocasiões em que precisavam impor mais respeito.

A Guarda Nacional era um corpo auxiliar da tropa de linha, o exército regular. Exercia função importante na manutenção da ordem pública, principalmente onde não havia polícia nem guarda municipal. Em 
caso de guerra, atuava como força auxiliar do Exército. Foi extinta em 1911, retirando dos grandes proprietários rurais um forte instrumento de poder. No entanto, a designação de coronel ficou associada aos chefes políticos municipais, em geral grandes proprietários de terras que, durante a República Velha, e mesmo depois, controlavam votos e tropas de jagunços ${ }^{3}$.

Assim como o patrimonialismo, o coronelismo também tem seu clássico. Publicado em 1949, depois de aprovado como tese universitária na Faculdade de Filosofia da Universidade do Brasil, Coronelismo, Enxada e Voto: O Município e o Regime Representativo no Brasil, de Victor Nunes Leal (1997), firmou-se como a referência incontornável em qualquer discussão sobre o assunto. Como o próprio título do livro indica, trata-se de um estudo sobre o papel do município na vida político-administrativa do Brasil, examinando, historicamente, suas atribuições, suas receitas, seu papel na organização policial e judiciária, a eletividade de seus mandatários e aspectos da legislação eleitoral. Entretanto, o primeiro capítulo traz as "Indicações sobre a Estrutura e o Processo do 'Coronelismo'", em que o autor discorre longamente sobre o tema, o que estimulou um colega a sugerir que ele pusesse o coronelismo em primeiro plano no título do livro, resultante da tese originalmente intitulada O Município e o Regime Representativo no Brasil: Contribuição ao Estudo do Coronelismo.

Para Leal, o coronelismo é fruto de um compromisso entre o poder público crescentemente fortalecido e os chefes políticos locais, notadamente os senhores de terras, em franca decadência. É o produto da implementação do regime representativo em uma estrutura social e econômica "inadequada". É uma manifestação do poder privado, ou o que restou de sua antiga exorbitância dentro da "ordem democrática". Tem como características secundárias "o mandonismo, o filhotismo, o falseamento do voto, a desorganização dos serviços públicos locais" (ibidem:41).

O coronelismo prospera em um meio em que há muita pobreza e grande concentração na posse da terra. Resultante da forma de ocupação do território ainda nos tempos da colonização, com a distribuição de sesmarias, a estrutura fundiária manteve-se concentrada mesmo com o parcelamento das heranças, uma vez que os casamentos entre membros de famílias proprietárias mantinham no domínio dos mesmos clãs as grandes fazendas. Por outro lado, os sitiantes, posseiros e arrenda- 
tários viviam em precárias condições, tendo de tirar seu sustento e remunerar o proprietário com a pequena produção da terra que conseguissem lavrar. Os pequenos proprietários também viviam na pobreza e na dependência dos grandes, a quem, muitas vezes, vendiam sua produção. Os próprios coronéis são quase sempre pouco mais do que remediados, vivendo modestamente, sem muito conforto, pois nem o excedente da produção nem o proveito que possam tirar das modestas obras e serviços dos governos municipais, eventualmente sob seu controle, lhes fornecem grandes rendimentos. Com seus recursos, eles têm de arcar com as despesas eleitorais - do alistamento e da eleição em si. Segundo Leal, "sem dinheiro e sem interesse direto, o roceiro não faria o menor sacrifício nesse sentido. Documentos, transportes, alojamentos, refeições, dias de trabalho perdido, e até roupa, calçado, chapéu para o dia da eleição, tudo é pago pelos mentores políticos empenhados na sua qualificação e comparecimento" (ibidem:56).

O coronel é, em geral, homem empenhado no progresso de seu distrito ou município, lutando por melhorias e obras, como escolas, estradas, postos de saúde, campos de futebol, postos do correio, luz elétrica e redes de água e esgoto. Para tanto, convém mais a ele dar sustentação ao partido governista.

Além de benefícios de interesse coletivo, o coronel também tem de prestar muitos favores pessoais, desde arranjar emprego até oferecer asilo e proteção a perseguidos pela Justiça. Para os adversários, contudo, nega pão e água. No exercício do favoritismo ou da perseguição, transita em uma zona que se encontra às margens da lei. O filhotismo o leva a trazer os agregados para comerem na gamela municipal. Nas batalhas eleitorais, utiliza inescrupulosamente o dinheiro, os bens e os serviços públicos municipais. A contraface do filhotismo é o mandonismo. O coronel se serve da máquina municipal ou das autoridades estaduais por ele nomeadas, como o delegado e o coletor de impostos, para perseguir seus opositores. Para os amigos, pão; para os inimigos, pau. É a troca de favores que está na base dos compromissos. É o descumprimento de uma promessa ou uma desconsideração pessoal qualquer que justifica a ruptura. Em geral, esta se dá para que o coronel possa voltar às hostes do oficialismo quando seu patrono perder o espaço no governo estadual. O sistema não estimula a rebeldia, que não oferece proveito àqueles que se afastam do governo. O apoio oficial é fundamental para trazer benefícios coletivos, oferecer favores, exercer pressão sobre os adversários e financiar parte das despesas eleitorais. 
O coronel não é um arrivista venal, mas é um realista, sempre atento à sua sobrevivência, que depende do amparo do governo estadual:

A essência, portanto, do compromisso "coronelista" - salvo situações especiais que não constituem regra - consiste no seguinte: da parte dos chefes locais, incondicional apoio aos candidatos do oficialismo nas eleições estaduais e federais; da parte da situação estadual, carta-branca ao chefe local governista (de preferência o líder da facção local majoritária) em todos os assuntos relativos ao município, inclusive na nomeação de funcionários estaduais do lugar (Leal, 1997:70).

Assim, o coronelismo nasce da falta de autonomia dos municípios, penalizados na ordem republicana pela redução de suas atribuições, pelo excesso de encargos e pela penúria orçamentária. Paralelamente ao enfraquecimento do poder local, cresceu a autonomia extralegal dos chefes políticos, que, em troca de votos, passam a opinar em todos os assuntos de interesse do município que se encontram na competência do Estado ou mesmo da União.

Em suma, o coronelismo é um compromisso entre um poder público estadual fortalecido e a reduzida influência social dos chefes políticos locais. É um sistema hierarquizado de alianças que delega aos coronéis a distribuição de benefícios e malefícios em troca da manipulação da vontade popular, o chamado "voto de cabresto"4. Medra à sombra do governo; nutre-se do oficialismo. Nada tem a ver com a antiga força dos senhores rurais do período colonial, autêntica afirmação do poder privado, única autoridade efetiva nos vastos sertões do Brasil.

Raymundo Faoro também se ocupou do coronelismo em sua extensa análise do patrimonialismo brasileiro. Para ser coerente com o argumento do estamento centralizador, Faoro acaba por minimizar o poder do coronel, colocando-o em condição subordinada, como um "servidor" do governador, de quem recebe delegação informal para exercer sua autoridade. Há um casamento entre o coronelismo (municipal) e a oligarquia (estadual).

Embora, em geral, o coronel seja um homem de posses, para Faoro pode haver, também, coronéis remediados que não sejam senhores de terras. Sua autoridade não provém da riqueza, mas do reconhecimento que se dá ao poder que exercem, recebido por delegação do governo central no Império e do governo estadual na República em troca dos votos que carreiam para o partido oficial. 
Segue, assim, a trilha aberta por Victor Nunes Leal e o núcleo de seu argumento, relacionado com o enfraquecimento do poder dos municípios e a relação de dependência para com o governo estadual. O coronelismo emerge do enfraquecimento dos municípios, com o esvaziamento de seus poderes e atribuições e o estrangulamento da eletividade de seus mandatários, desde a constituição republicana. Nesse quadro, estabelece uma relação de obediência entre o governador, "intermediário dos favores e benefícios da União sobre as comunas" (Faoro, 2001:708), e o coronel. Entre um e outro a relação é de obediência.

Os coronéis não são, portanto, parte do estamento político-burocrático que domina o Estado nacional. São um poder auxiliar, subordinado, que lhe serve à distância, concentrado em aspectos da vida local. É no mínimo curioso que Faoro passe praticamente ao largo da análise do municipalismo e das questões relativas ao sistema representativo que constituem o objeto da tese de Leal. Ora, no Portugal patrimonialista e na administração colonial, os concelhos constituíam uma força representativa da vontade dos munícipes contra a afirmação do poder dos grandes proprietários rurais. No Império brasileiro, houve uma amálgama dessas duas forças que, isoladas dos grandes centros e dos interesses que neles se debatiam, exerciam sua dominação sem incomodar nem serem incomodadas pelo governo central. O poder local era, pois, uma peça-chave na sustentação da ordem estamental. Na República, o município enfraquecido e o coronelismo dependente são o combustível do poder das oligarquias estaduais, estas, sim, forças emergentes a confrontar o governo central e o estamento.

O terceiro livro que expõe o tema do coronelismo também se converteu em um clássico. Coronel, Coronéis, de Marcos Vinícios Vilaça e Roberto Cavalcanti de Albuquerque (1965), texto de leitura bastante agradável, reproduz os mesmos argumentos de Leal. Restrito ao ambiente do Nordeste, o traço original dessa pesquisa é a construção de perfis sociobiográficos de quatro remanescentes, cada um com seu estilo, da mais pura estirpe do coronelismo nordestino. Constituiu então uma novidade na ciência social brasileira, pois introduzia, à moda dos pioneiros de Chicago, a história de vida como método de pesquisa qualitativa. Chico Romão, Zé Abílio, Chico Heráclio e Veremundo são bem diferentes entre si, mas, mesmo em suas particularidades, configuram um modelo geral que, devidamente estilizado, poderia evoluir para a formulação do ideal-tipo weberiano. 
O ensaio introdutório e os quatro perfis constituem a crônica de uma morte anunciada, como de resto também o fazem os outros textos clássicos. Os autores pernambucanos descrevem a dependência dos coronéis com relação ao governo estadual e registram a decadência do sistema que lhes dá sustentação. $\mathrm{O}$ voto mercadoria acaba por se enquadrar na lei da oferta e da procura, podendo ser vendido a quem por ele pagar mais. Por outro lado, os benefícios que o coronel precisa levar para sua comunidade para demonstrar prestígio e assegurar legitimidade se transformam em armas contra a própria estrutura de dominação. Escolas, estradas, estações de rádio, empreendimentos industriais, tudo isso contribui para acelerar os processos que transformam a estrutura socioeconômica e minam as bases do coronelismo.

O estudo sobre o coronelismo e o mandonismo ganhou novo alento com os trabalhos de Maria Isaura Pereira de Queiroz. Tomado em perspectiva histórica, o coronelismo se inscreve em uma longa tradição de mandonismo local, presente na vida política brasileira desde a colonização. Sua permanência se deve à conservação na estrutura social do latifúndio e da "família grande", em um jogo de ação e reação com o poder central que progressivamente se afirma - pálido ainda na Colônia; imbricado com o mandonismo local no Império; independente e fortalecido na República, sobretudo a partir de 1930.

Seria ocioso retomar todo o desenvolvimento de seu raciocínio e seus argumentos para mostrar a força do mandonismo em quatrocentos anos de história. Na Colônia, as sesmarias latifundiárias, a família patriarcal, o trabalho escravo e as câmaras plenipotenciárias constituíam a base da dominação senhorial. No Império, um débil governo central, longe da numerosa população rural, apoiava-se nos mandões, em um jogo de laisser-faire, de não interveniência nos assuntos internos de um e outro, legitimando sua autoridade com as dragonas das patentes da Guarda Nacional. Na República Velha, a emergência do coronelismo se deve ao enfraquecimento da autonomia municipal, que era compensado pela forma peculiar de funcionamento do sistema representativo, requerendo a chancela do voto para confirmar as escolhas dos representantes. Todas essas transformações históricas são minuciosamente descritas no ensaio sobre O Mandonismo Local na Vida Política Brasileira e Outros Ensaios (Queiroz, 1976).

Nem a libertação dos escravos, nem o advento da República, nem o aumento da dependência municipal imposto pelo regime de 1891 deram 
cabo do mandonismo. Ao contrário, os chefes locais souberam se adaptar ao "trabalho livre" de camponeses sem terra e de imigrantes estrangeiros, à ampliação da participação política com a extensão do direito de voto e ao sistema de transação com o poder emergente das oligarquias estaduais. Agora, a ideologia do favor dava sustentação ao mecanismo de barganha que mantinha o coronel no centro da intermediação.

O singular no estudo de Queiroz é a ideia de permanência, de sustentabilidade do poder coronelista: "O centro da política continuava, malgrado todas as limitações estabelecidas por lei, o município, e dentro do município, o coronel, do mesmo modo que durante o Império" (1976:117). Ele se interpunha entre a massa votante e o chefe político estadual, distribuindo favores, conciliando interesses, arrebanhando eleitores. Vigia um acordo tácito: “[...] o governo não se metia no município, onde o coronel tinha carta branca para fazer o que quisesse, e em troco recebia o apoio do coronel" (ibidem:118).

O caso mais extremado de exercício do mandonismo, relatado por Queiroz, e também citado por Leal e Faoro, é o do padre Cícero Romão Batista. Figura emblemática de líder político e religioso, exerceu durante mais de cinquenta anos o domínio do município de Juazeiro do Norte e de toda a região sul do Ceará. Por doze anos prefeito da cidade, foi eleito e reeleito vice-presidente do Estado e, com o apoio de outros coronéis, derrubou o presidente do Ceará, Franco Rabelo, para restaurar o poder da oligarquia tradicional. Em seu território agia sobranceiro, indiferente aos ditames do governo estadual, que enviava embaixadores para cortejá-lo. Três presidentes estaduais ${ }^{5}$ foram a Juazeiro visitá-lo, em uma penosa viagem por estradas de terra de mais de $600 \mathrm{~km}$. Em sua praça-forte, acolhia com hospitalidade quem o procurasse em missão de paz, até mesmo bandidos de honra, como Lampião e seu bando. Tornou-se célebre o pacto firmado em 4 de outubro de 1911, sob sua direção, por dezessete chefes políticos do Vale do Cariri para fazer cessar hostilidades e impor a pax "romana". O documento estabelecia o desarmamento, o apoio mútuo contra as tentativas de golpe, a via do acordo para superar desavenças e o poder moderador do chefe supremo do partido (Faoro, 2001:724).

No ensaio específico sobre o coronelismo, além da recuperação histórica, há a perspectiva sociológica, a preocupação conceitual e o estabelecimento de categorias de análise. O coronelismo é visto como "uma 
forma específica de poder político brasileiro que floresceu durante a Primeira República, e cujas raízes remontam ao Império" (Queiroz, 1976:163). O fenômeno persiste; forma um sistema em que o coronel é o elemento polarizador em torno do qual os indivíduos se distribuem no espaço social segundo diferentes níveis hierárquicos, mas são todos "gente do coronel". É, portanto, um sistema de poder, apoiado nas relações pessoais, diretas ou indiretas, que distribui proteção e controla votos, convertidos em bens de troca. Embora estratificada, a estrutura permite certa mobilidade ascendente, que se dá pela aquisição de fortuna ou pela aproximação ao centro do sistema ou subsistema regional ou local. Assim, existem coronéis em vários graus, desde os pequenos, dominando diretamente certo número de eleitores, até os grandes, liderando um grupo de outros coronéis. Os pequenos quase se equiparam aos cabos eleitorais, que mantêm contato direto com os eleitores e intermedeiam os favores que recebem dos coronéis. Essa multiplicidade de níveis constituía, na visão de Queiroz, uma singularidade da política brasileira durante a Primeira República, traço de sua estrutura socioeconômica apoiada em grupos de parentela consanguínea ou econômico-política. Esse aspecto se transformou com o tempo, perdendo relevância depois da Revolução de 1930. Por isso, Queiroz prefere designar os chefes políticos, proprietários de terras ou não, que dominaram o meio rural desde a Colônia de "mandões locais":

O coronelismo se integra, pois, como um aspecto específico e datado dentro do conjunto formado pelos chefes que compõem o mandonismo local brasileiro - datado porque, embora aparecendo a apelação de "coronel" desde a segunda metade do Império, é na Primeira República que o coronelismo atinge sua plena expansão e a plenitude de suas características. O coronelismo é, então, a forma assumida pelo mandonismo local a partir da Proclamação da República: o mandonismo local teve várias formas desde a Colônia, e assim se apresenta como o conceito mais amplo com relação aos tipos de poder político-econômico que historicamente marcaram o Brasil (ibidem:172).

Trata-se, pois, de uma estrutura de dominação em que os dominantes dispõem de vários instrumentos, principalmente o econômico, mas também de armas como a opressão, a violência e a crueldade, "tão empregados e tão usuais quanto os favores e os benefícios", para captar e conservar votos (ibidem:174). O regime de proteção e coerção, pouco a pouco, cede lugar à barganha, na medida em que a "igualdade" entre 
os eleitores e entre eles e os eleitos transformam o voto em um valioso bem de troca.

Para Queiroz, o coronelismo está em declínio, vitimado pelo avanço do crescimento demográfico, da industrialização, da urbanização. $\mathrm{O}$ aumento do número de eleitores, o surgimento de camadas médias urbanas, a elevação dos níveis educacionais, a melhoria do sistema de transportes e a ampliação do acesso aos meios de comunicação são processos que concorrem para arruinar a estrutura coronelista, uma vez que intensificam a diferenciação social. De fato, eles encurtam distâncias sociais e geográficas, despersonalizam as relações sociais e aumentam a consciência crítica, dificultando o exercício de uma autoridade extralegal. A análise de Queiroz mostra, portanto, que vários fatores conjugados determinaram a decadência da estrutura coronelista, fazendo-se sentir de forma diferente segundo as características de cada região. Mas o coronelismo, ou alguns de seus aspectos, ainda persistia na vida política brasileira.

Muitos outros trabalhos foram escritos na esteira desses clássicos pioneiros, sempre tomando como referência maior o Coronelismo, de Victor Nunes Leal, conforme já repertoriava o trabalho de Carone (1971) e a bibliografia do texto de José Murilo de Carvalho (1997). São diferentes nuanças, perspectivas de análises e, sobretudo, estudos de caso que mostram, se não a permanência do fenômeno, pelo menos o interesse por seu estudo. Convém mencionar, ainda que de forma muito breve, três desses trabalhos, tomados quase ao acaso a partir do fato de serem mais recentes.

João Gualberto (1995) relata o caso do Espírito Santo tomando como exemplo a presença de Jerônimo Monteiro na vida política de um estado caracterizado pela ocupação territorial por meio da imigração de europeus. O oligarca governou o Espírito Santo de 1908 a 1912, mas influenciou a política do estado até sua morte, em 1933, tendo elegido seu irmão, Bernardino Monteiro, presidente do estado em 1916 e, ele mesmo, senador em 1918 e constituinte em 1933. O trabalho de Gualberto também trata das heranças do coronelismo, oferecendo um breve panorama da política estadual até meados dos anos 1960, destacando o capital político transmitido aos populistas e tecnocratas. O principal legado é a inscrição do coronelismo no imaginário político brasileiro, manifestando-se na literatura e informando as representações sociais do poder local. 
João Morais de Sousa (1995) estudou a vida política do município de Malta, no interior da Paraíba, de 1953 a 1992, onde constata a conservação do poder político nas mãos dos chefes locais, que se mantém mediante práticas de cunho assistencialista, paternalista e clientelista. Entre vários outros aspectos, pode-se questionar, nesse trabalho, a própria apresentação do caso de Malta como uma estrutura coronelista, descrita de forma semelhante às de centenas de outros municípios do Nordeste. No entanto, convém registrar as práticas que indicam fazerem parte do repertório coronelista - assistência médica, empreguismo, crimes eleitorais, perseguições, relações de compadrio, rituais fúnebres e celebrações religiosas, e a conversão de direitos sociais, como a aposentadoria rural, em favores. As categorias são confusas, pois embaralham espécies, gêneros e famílias, mas oferecem bons exemplos do clientelismo que preside as relações políticas no nível local.

Um dos trabalhos mais recentes sobre o tema do coronelismo é o de Araújo (2006), uma tese de doutorado que, entre outros temas, trata da trajetória política de José Sarney. A partir do Estado do Maranhão, fez-se deputado, senador, presidente do Congresso e presidente da República. É, ainda hoje, senador, chefe de clã familiar e político, pai da ex-governadora e senadora pelo Maranhão e figura proeminente da República. O emprego do conceito de coronelismo parece inadequado ao ser aplicado ao caso específico dos Sarney, uma oligarquia poderosa, sim, que se alimenta do "sistema" baseado no mandonismo local.

A propósito, Carvalho (1997) procura, sem muito sucesso, desfazer os equívocos conceituais no uso das noções de mandonismo, coronelismo e clientelismo, cuja distinção é fundamental para o estudo das relações entre o poder local e o poder nacional, inclusive para este artigo. Valendo-se da releitura do clássico de Leal, Carvalho procura acentuar as diferenças entre o coronelismo e o mandonismo. Conforme assinalara Leal (1997), o coronelismo aparece como um sistema político, datado da Primeira República, que descreve uma complexa rede de relações que vai desde o coronel até o presidente da República, nascida da convergência de dois fatos - o surgimento da figura forte dos governadores estaduais e a decadência econômica dos fazendeiros.

O mandonismo, conceito que se aproxima do caciquismo hispano-americano,

refere-se à existência local de estruturas oligárquicas e personalizadas de poder. O mandão, o potentado, o chefe, ou mesmo o coronel como in- 
divíduo, é aquele que, em função do controle de alguns recursos estratégicos, em geral, a posse da terra, exerce sobre a população um domínio pessoal e arbitrário que a impede de ter livre acesso ao mercado e à sociedade política. O mandonismo não é um sistema, é uma característica da política tradicional (Carvalho, 1997:3).

Enquanto o coronelismo morreu em 1930 e foi enterrado em 1937, o mandonismo existe desde a colonização e sobrevive, ainda hoje, em regiões isoladas, embora tenda a desaparecer com a ampliação dos direitos de cidadania. O uso das expressões "sistema" e "estrutura" para designar um e outro acaba por manter a confusão. Apesar disso, a distinção proposta indica que o coronelismo designa um sistema político, e o mandonismo uma característica pessoal do chefe político, embora seja difícil distinguir um do outro. Parece razoável supor que determinados sistemas políticos favorecem a emergência de tipos específicos de chefia.

Nesta análise, preferiu-se considerar, como o faz Queiroz, o coronelismo uma variedade de mandonismo, "um momento particular do mandonismo", como também anotou Carvalho a respeito da visão de Leal. Nesse caso, o mandonismo é também um sistema, que se transforma historicamente, e não o exercício do poder absoluto, como pretendia Eul-Soo Pang (1979), mas sim um sistema de dominação clientelista em que o poder pessoal e a arbitrariedade ainda dão algumas cartas. $\mathrm{O}$ fato de o mandonismo a parecer como "uma característica do coronelismo" só confirma a proximidade entre as duas categorias. Se "a história da decadência do mandonismo confunde-se com a história da formação da cidadania" (Carvalho, 1997:3), identifica-se também com a história do desenvolvimento da poliarquia, da burocratização do Estado e do declínio do coronelismo.

Considerado dessa perspectiva, o mandonismo é um sistema que permanece. O coronel, o patriarca do sertão, vestido em blusões de linho e calçado em alpercatas, cercado de jagunços, tangendo gado, posseiros e eleitores, distribuindo favores e fazendo justiça, vendo o rebanho e o mundo a partir dos alpendres de suas casas de fazenda, não existe mais. Mas a política municipal continua comandada por chefetes personalistas muitas vezes arbitrários no exercício de seus limitados poderes. O coronel, proprietário de terras, transfigurou-se no comerciante, no médico, no gerente de banco, que entram na política local para modernizá-la e acabam por adotar as mesmas práticas daqueles que 
substituem. Eles apoiam as oligarquias estaduais e o partido da situação. Seus representantes no Congresso Nacional formam a maioria parlamentar de todos os governos de ontem e de hoje. O traço forte dessa política é o clientelismo. Nesse sentido, mais do que o mandonismo, o coronelismo subsiste como representação social do Brasil profundo.

Existindo como dado de realidade ou como representação coletiva, o coronelismo também informa os projetos de reforma do Estado. Com a visão do coronelismo como uma força do atraso a sustentar o patrimonialismo e a solapar a eficiência da administração pública, os reformistas tendem a ser "apolíticos" e centralizadores. Acreditam que o poder local pode ser facilmente capturado pelos mandões locais. Assim, convém manter políticas apoiadas na centralização de recursos e no controle rígido sobre os repasses aos níveis inferiores de governo.

Munidos de novos conceitos (rent-seeking society), atualizam estratégias de insulamento (pós-)burocrático (Nunes, 1997), defendendo a criação de agências autônomas, organizações sociais e outros instrumentos imunes à influência "nefasta" da política partidária. Comprometidos com o ideário do gerencialismo, engajam-se em governos "modernizadores" apoiados pelas mesmas forças que dizem querer eliminar.

\section{PERSONALISMO}

Utiliza-se, aqui, o personalismo (ou "pessoalidade") para caracterizar uma forma particular de hierarquização social baseada na distinção entre indivíduos e pessoas proposta por Louis Dumont e introduzida na "sociologia do dilema brasileiro" pelo antropólogo Roberto DaMatta (1980).

Às clássicas análises do patrimonialismo e do coronelismo vem se somar uma interpretação do Brasil que coloca em primeiro plano a cultura e suas manifestações. Trata-se de Carnavais, Malandros e Heróis, de DaMatta, livro também já convertido em clássico, que tenta desvendar o dilema brasileiro como um drama, a partir do estudo de seus rituais e de seus personagens principais. $\mathrm{O}$ autor se propõe a discutir as peculiaridades de nossa sociedade, "o que faz o Brasil, Brasil", o país de "carnavais e hierarquias, igualdades e aristocracias, com a cordialidade do encontro cheio de sorrisos cedendo lugar, no momento seguinte, 
à terrível violência dos antipáticos 'você sabe com quem está falando?'" (ibidem, 1980:14).

Para construir essa interpretação, DaMatta apresenta um conjunto de ensaios em que trata dos ritos do Carnaval e do Dia da Pátria, dos mundos da Casa e da Rua, da comparação entre os carnavais do Rio de Janeiro e de New Orleans, do ritual do "você sabe com quem está falando?", da figura do malandro e da literatura de Guimarães Rosa, destacando as personagens emblemáticas da malandragem, da vingança e da renúncia. São diversas ocasiões para chamar a atenção para o caráter relacional da sociedade brasileira.

Todas as sociedades estabelecem formas de hierarquizar seus membros. No Brasil, a hierarquização se reproduz em múltiplos planos, com critérios outros além do eixo econômico dominante. Serve para compensar e complementar diferenciações sociais básicas, incorporando classificações para cor, origem, educação, relações pessoais etc.: "Aqui, as relações pessoais mostram-se muito mais como fatores estruturais do sistema do que como sobrevivências do passado que o jogo do poder e das forças econômicas logo irá colocar de lado e marginalizar" (ibidem:192).

Na sociedade relacional, os requisitos do domínio racional-legal, ou seja, os elementos que conferem racionalidade e legitimidade à dominação burocrática, como a igualdade perante a lei, a universalidade na aplicação da norma e o princípio da isonomia, estão sujeitos à hierarquização social que distingue "indivíduos" de "pessoas" e posiciona seus membros de acordo com o peso de seus relacionamentos. Por isso, a todo momento somos levados a introduzir elos personalizados em atividades basicamente impessoais.

A presente análise se vale, sobretudo, dos insights apresentados no capítulo "Você Sabe com Quem Está Falando?". Essa expressão, de uso cada vez menos frequente, sempre foi utilizada no Brasil para destacar a posição social de quem a enuncia em uma situação na qual se sente "rebaixado" ou posto em igualdade de condições em um momento em que esperava tratamento diferenciado ou obter privilégios. Constitui um ritual que (r)estabelece a hierarquia em um universo que tende ao igualitarismo. Coloca em primeiro plano uma hierarquia que se deseja esconder, até por se considerar desnecessária, pois "cada qual deve saber o seu lugar". É o contraponto do "jeitinho" (nossa maneira especial de resolver as coisas), da malandragem e da cordialidade, característi- 
cas sempre tomadas como referência para definir o modo de ser brasileiro. É, portanto, um ritual que não se percebe como dramatização da afirmação das hierarquias, "atualização de valores e princípios estruturais de nossa sociedade" (ibidem:142), mas como uma manifestação de características pessoais indesejadas. O ritual chama a atenção para conflitos reais ou latentes em uma sociedade que tem aversão aos conflitos, concebidos

como presságios do fim do mundo, e como fraquezas - o que torna difícil admiti-los como parte de nossa história, sobretudo nas suas versões oficiais e necessariamente solidárias. Tomamos, então, o partido de sempre privilegiar nossas vertentes mais universalistas e cosmopolitas, deixando de lado uma visão mais percuciente e genuína de nossos problemas (DaMatta, 1980:141).

Note-se que o ritual hierarquizante também é utilizado por camadas sociais supostamente desprovidas de posições que possam evocar dominância. Essa possibilidade destaca o aspecto relacional da posição de superioridade, pois o subalterno pode se valer da posição do chefe, o empregado da do patrão, o parente humilde da do patriarca poderoso, agindo como se nelas estivessem. Nesse sentido,

a hierarquia parece estar baseada numa intimidade social. [...] As rela-
ções podem começar como marcadas pelo eixo econômico do trabalho,
mas logo depois adquirem uma tonalidade pessoal, definindo-se tam-
bém no plano de uma forte e permanente moralidade. [...] Numa socie-
dade assim constituída, onde as relações de trabalho somam-se a um
conjunto de laços pessoais regidos por valores tais como a intimidade
$[\ldots .]$, a consideração, o favor [...], o respeito [...] e apreciações éticas e estéti-
cas generalizantes (como as categorias de limpo, bem-apessoado, cor-
reto, sagaz, bom, de fino-trato, etc...), existem possibilidades para uma
hierarquização contínua e múltipla de todas as posições no sistema,
mesmo quando elas são radicalmente diferenciadas ou formalmente
idênticas (ibidem:148; ênfases do autor).

Assim, além do eixo econômico dominante que prevalece nas sociedades de mercado, incorpora-se o capital de relações sociais como um elemento fundamental na hierarquização social, criando-se um sistema múltiplo que serve para estabelecer compensações e complementaridades e, ao mesmo tempo, reforçar a estratificação. Essa dialética do sistema dificulta a tomada de consciência das posições sociais e atuali- 
za o mito da democracia racial, da mobilidade instantânea e da cordialidade nas relações entre dominantes e dominados.

Na busca de construir uma compreensão da sociedade relacional, com base no ritual do "você sabe com quem está falando?", DaMatta introduz a distinção entre indivíduo e pessoa que recupera da literatura antropológica, sobretudo de Marcel Mauss e Louis Dumont. Embora não fique explícito, parece claro que a noção de pessoa está mais associada às sociedades tradicionais, e a noção de indivíduo às sociedades modernas. Pessoas são englobadas por comunidades totalizantes, expressam sentimentos coletivos, obedecem a regras tradicionais, têm reduzida capacidade de escolha. Os indivíduos são livres, expressam subjetividades, fazem as regras do mundo onde vivem e suas possibilidades de escolha constituem direitos.

Considerada nesses termos, a distinção conceitual parece separar dois mundos estanques, quando o que caracteriza a apropriação que dela faz DaMatta é justamente sua dinâmica e as múltiplas possibilidades de combinação e gradação. Assim como existem pessoas nas sociedades igualitárias de mercado, como os Estados Unidos (very important people), há, em caráter excepcional, indivíduos nos sistemas tribais, pessoas que se individualizam pela recusa da totalidade.

Existe, desse modo, uma complexa dialética entre o indivíduo e a pessoa, havendo sistemas que privilegiam um ou outro. O Brasil caracteriza-se pela importância atribuída às duas noções, quer dizer, pelo valor conferido às leis universalizantes que promovem a igualdade dos indivíduos e, ao mesmo tempo, aos critérios morais e afetivos que hierarquizam as pessoas.

DaMatta acredita que

por termos leis geralmente drásticas e impossíveis de serem rigorosamente acatadas, acabamos por não cumprir a lei. E, assim sendo, utilizamos o clássico "jeitinho" que nada mais é do que uma variante cordial do "Você sabe com quem está falando?" e outras formas mais autoritárias que facilitam e permitem burlar a lei ou nela abrir uma honrosa exceção que a confirma socialmente (ibidem:184).

Esses escapismos acabam por gerar desconfiança com relação às regras universalizantes e atualizar a vigência do formalismo (Riggs, 1964; 1968), quer dizer, a discrepância entre as normas prescritas legalmente e o comportamento efetivo dos sujeitos. 
O formalismo, entretanto, pode ser visto também como a expressão de um ideal de sociedade e, portanto, como uma estratégia de mudança social: "A força da lei é, pois, uma esperança. Para os destituídos, ela serve como alavanca para exprimir um futuro melhor (leis para nós e não contra nós) e para os poderosos, ela serve como um instrumento para destruir o adversário político. Num caso e no outro, a lei raramente é vista como lei, isto é, uma regra imparcial" (DaMatta, 1980:185).

No universo das relações pessoais, a lei não é a expressão da ordem igualitária, mas sim uma sanção generalizada, da qual não escapam aqueles que conseguem flexibilizar sua vigência pela "especificidade do caso". Quem se apresenta como "indivíduo" não é um cidadão completo; é um "zé-ninguém", uma "não pessoa", alguém que não possui uma "identidade" que possa ser hierarquizada em uma escala relacional - filho do ministro, amigo do deputado, irmão do coronel, motorista do governador. Esse "indivíduo", para quem está dos dois lados do balcão a burocracia pública, não é percebido como o patrão, o cliente e a própria razão de ser do Estado e dos serviços públicos. É um incômodo, um estorvo.

Uma das críticas que se faz ao trabalho de DaMatta é a mesma que se dirige às teses de Faoro. Segundo essa perspectiva, as análises desses intérpretes da realidade brasileira acabam por identificar a permanência de traços das sociedades tradicionais, sobretudo em seus aspectos culturais, vale dizer, a ação afetiva (Weber, 1994), as características da comunidade (Tönnies, 1947), as formas de solidariedade mecânica (Durkheim, 1991) e outros elementos holísticos. A crítica a essas concepções se refere a uma sociologia da inautenticidade, que negaria a completude do processo de modernização brasileira, deixando por toda parte as sombras e os escombros do passado tradicional.

Souza (2000) aprofunda essa crítica em duas direções. Primeiro, mostra que as noções de indivíduo e pessoa e os valores a elas associados não estão vinculados a um esquema de estratificação social que os hierarquize, ou seja, não permitem explicar "a imbricação entre domínio ideológico e acesso diferencial a bens ideais ou materiais escassos" (ibidem:191). Segundo, nega a nitidez da distinção entre os espaços da casa e da rua, onde transitam conjuntos diferentes de valores, afirmando a ubiquidade dos valores veiculados pelas instituições do Estado e do mercado. O mundo da casa não seria infenso à lógica da economia monetária e à internalização do controle das pulsões imposta pelo conti- 
nuado exercício do monopólio da violência por parte do Estado (ibidem:194-195).

Escapa aos objetivos deste artigo aprofundar esse debate. Para a discussão do personalismo, é suficiente assinalar que a crítica de Souza é pertinente ao identificar uma confusão entre esferas de ação e espaços sociais distintos, o que permitiria mudar a percepção das formas de inserção do indivíduo (às vezes, convertido em pessoa) na vida social. No entanto, exclui a possibilidade de que se possa pensar as noções de indivíduo e pessoa e de casa e rua como categorias, cuja gramática opera no mundo das representações, ora estabelecendo vinculações com classes e grupos sociais, situações de gênero e gerações, ora transitando com relativa autonomia entre esses espaços. Por outro lado, os valores veiculados pelo Estado e pelo mercado, ainda que assimilados por toda a sociedade, por vezes de forma antropofágica, podem sê-lo de maneira diferenciada, segundo aquelas mesmas formas de segmentação social que definem diferentes representações do mundo.

Essa observação é importante porque coloca em primeiro plano a forma ambígua com a qual o personalismo se apresenta à sociedade brasileira e informa a maneira como ela define a si mesma. Nesse caso, as situações concretas em que o elemento relacional é evocado em uma relação impessoal são numerosas e, conforme o caso, podem ser encaradas, com maior ou menor tolerância, como recursos à hierarquização ou como sinal de flexibilidade e cordialidade.

Do ponto de vista dos reformadores, embora muitos deles possam se prevalecer da posição privilegiada que ocupam na administração pública para fazer render seu capital de relações pessoais, não há ambiguidade - o personalismo é sempre visto de forma negativa.

De todos os clássicos das teorias do Brasil, DaMatta é provavelmente o menos lido entre os reformadores, embora, em anos recentes, venha crescendo o número de analistas que incluem a sociedade relacional no contexto da reforma do Estado. É verdade que a dimensão cultural sempre esteve presente nas cogitações dos estudiosos da mudança institucional, desde Visconde do Uruguai, Alberto Torres, Oliveira Vianna, Guerreiro Ramos e Hélio Beltrão, mas, além de reconhecerem a impossibilidade de mudar a cultura por decreto, pouco oferecem em termos de proposições que não se circunscrevem no plano das transformações estruturais ou da própria mudança institucional. 
Se é certo que as instituições não se reproduzem da mesma maneira acima e abaixo do Equador, quais consequências poderia ter para as propostas de reforma administrativa a consciência de que vivemos em uma sociedade que distingue indivíduos de pessoas, utiliza múltiplos critérios de hierarquização social e se vale de práticas rituais como o "você sabe com quem está falando?" e o "jeitinho"?

Qualquer que seja a disposição relativista dos estudiosos, é certo que a pessoalidade e os rituais que a atualizam podem ser tomados como aspectos da cultura brasileira que se projetam sobre a administração pública e se contrapõem a princípios de universalidade, isonomia e equanimidade que devem presidir as relações entre a administração pública e os cidadãos. Nesse sentido, os esforços de reforma realizados até 1980 sempre se orientaram na direção da burocratização do Estado, tentando impor o princípio da impessoalidade e afastar dos negócios públicos quaisquer influências estranhas a seu universo.

A partir de então, as propostas de reforma de cunho gerencialista têm se orientado para a flexibilização da gestão pública e a incorporação de organizações não governamentais à prestação de serviços públicos, em uma tentativa de superar o modelo burocrático. O problema é que, ao abrir espaço para a atuação de organizações de caráter particularista, com compromissos de caráter moral, político ou religioso específicos, a reforma gerencial pode ameaçar o universalismo de procedimentos.

Quando ainda há tantos déficits de institucionalidade democrática, a superação do modelo burocrático deve ser feita com muita cautela. A burocracia, fundada na isonomia e na neutralidade, está na base dos sistemas igualitários. Querer substituir de chofre o universalismo burocrático pelo particularismo das organizações não governamentais pode ser uma temeridade em uma terra onde ainda há fortes traços de mandonismo, clientelismo, nepotismo e fisiologismo. Querer trocar a ética burocrática por pseudoincentivos pecuniários pode ser um disparate.

Por outro lado, desde que não se imponha como um mecanismo de hierarquização e discriminação, a pessoalidade, enquanto representação de uma relação menos formal, fria e distante, pode ser vista como um elemento importante para quebrar a rigidez dos sistemas burocráticos. No mundo privado, as estratégias orientadas para a fidelização de clientes passam por um processo de "pessoalização" das relações entre produtor e consumidor. No mundo dos serviços públicos, a instituição 
da figura do médico de família é uma forma de estabelecer uma relação baseada no conhecimento mútuo, uma relação pessoalizada.

O desafio que se impõe aos reformadores é reconhecer a pessoalidade como uma representação das relações entre indivíduos, propor medidas de caráter universalista para reduzir seus impactos hierarquizantes e discriminatórios e tirar proveito de sua valorização como elemento capaz de "humanizar" as relações entre a burocracia e os cidadãos (diferenciados em suas necessidades).

\section{PRÁTICAS, REPRESENTAÇÕES, TEORIZAÇÕES E REFORMAS}

O estudo das categorias centrais da sociologia política brasileira, usadas para definir as relações entre o Estado e a sociedade, revela que o patrimonialismo, o coronelismo e o personalismo constituem referências importantes para o debate sobre a reforma do Estado. Elas informam as atitudes intelectuais, os diagnósticos e as propostas de mudanças dos reformadores de todas as latitudes conceituais e ideológicas. São conceitos curinga que se prestam a variados usos e servem, algumas vezes, para apoiar até mesmo teses conflitantes. Tanto podem se referir a aspectos da realidade observável quanto a reminiscências históricas e apreciações ligeiras sobre a sociedade brasileira. São categorias sociológicas e representações sociais.

No caso do patrimonialismo, verificou-se que constitui o conceito mais frequentemente lembrado em todas as análises históricas e diagnósticos sobre o Estado e a administração pública brasileira. A maioria dos estudos o toma como uma etapa do desenvolvimento administrativo que teria deixado resíduos patrimonialistas presentes em determinadas práticas de privatização da esfera pública ou como um dado cultural que se entranhou na mentalidade brasileira. Alguns poucos trabalhos, por causa do uso impreciso do conceito, confundindo-o com o clientelismo, o corporativismo e até mesmo com a simples corrupção, asseguram tratar-se de dado de realidade verificável em inúmeras evidências. No primeiro caso, a atitude intelectual de reconhecimento da superação do patrimonialismo leva a políticas de reforma orientadas para a desburocratização e a flexibilização da gestão pública. No segundo caso, a atitude de denúncia da presença do patrimonialismo leva a estratégias focadas na intensificação dos controles administrativos, políticos e sociais. Uma terceira posição reconhece a superação do patrimonialismo, mas constata as fragilidades dos direitos de cidada- 
nia, do funcionamento de determinadas instituições e dos mecanismos de controle político e social, o que implica assegurar a vigência de alguns princípios da administração burocrática - a universalidade, a isonomia e a equanimidade. Em todos os casos, o patrimonialismo, como imagem simbólica e representação, paira como uma sombra sobre o passado, o presente e o futuro.

Com relação ao coronelismo, embora ainda apareçam muitos estudos destinados a comprovar sua permanência, seu uso como categoria de base para informar análises e diagnósticos sobre a administração pública é mais implícito do que manifesto. Mais uma vez, a confusão conceitual leva alguns analistas a tomarem por coronelismo ou mandonismo manifestações de clientelismo municipal. A existência dessas práticas e os déficits de institucionalidade e competência gerencial das administrações locais muitas vezes têm orientado a adoção de estratégias centralizadoras na formulação e na implementação de políticas públicas, com impactos na organização governamental e na distribuição de competências entre níveis de governo. Os fantasmas do patrimonialismo e do coronelismo informam reformas e estratégias "despolitizadas", políticas concentradoras e controles centralizados apoiados no insulamento burocrático (Nunes, 1997).

Como os demais conceitos, o personalismo às vezes é objeto de imprecisão conceitual, sendo confundido com compadrio, filhotismo, nepotismo e outros "vícios" supostamente herdados da sociedade tradicional. A não ser nos casos de combate direto ao nepotismo, em geral fica implícito no discurso moralizante dos reformadores. Tomado ora como um dado quase natural da sociabilidade brasileira, ora como uma distorção a ser combatida (em geral, quando confundido com outras formas de privilégio e favorecimento), o personalismo está situado em um plano inconsciente, encoberto pelo manto do naturalismo ou pelo mecanismo freudiano da projeção. Todos buscam valer-se de seu capital de relações pessoais para evitar uma fila, acelerar um processo, obter uma concessão. Na forma como está aqui descrito, o personalismo não pode ser superado por projetos de reforma ou novas leis universalistas. As reformas e as políticas públicas podem atenuar seus efeitos hierarquizantes e discriminatórios e tirar proveito da valorização positiva que lhe é conferida para estabelecer relações menos frias e distantes entre burocratas e usuários de serviços públicos. 
Essas três categorias constituem expressões de práticas sociais e diferentes formas de representar as relações entre o Estado e a sociedade, entre os domínios público e privado. Suscitam atitudes mentais com relação à autoridade e seus limites, à distribuição do poder político, à res publica, à burocracia e à cidadania. Informam julgamentos e atitudes de políticos, reformadores, burocratas e cidadãos.

Situar esses conceitos no contexto da reforma do Estado significa examiná-los não só enquanto categorias definidoras de aspectos da realidade, mas também como representações do mundo social e político. Significa desvendar as máscaras impostas pelo naturalismo, revelar atitudes intelectuais implícitas em diagnósticos aparentemente neutros e consistentes e identificar as respostas, em termos de propostas de mudança, dos reformadores a suas próprias formas de assimilação dessas noções. Significa, ainda, avaliar o alcance da influência das práticas e representações que elas definem sobre o funcionamento da administração pública brasileira e sobre as propostas para reformá-la. Patrimonialismo, coronelismo e personalismo designam manifestações extintas ou em vias de extinção que continuam a existir nos corações e mentes de governantes, reformadores e cidadãos, instruindo comportamentos e projetos de mudança e, aqui e acolá, ensejando práticas.

(Recebido para publicação em julho de 2008) (Versão definitiva em março de 2009) 


\section{NOTAS}

1. A imagem simbólica é um dos dois instrumentos básicos da política simbólica definida por Lucien Sfez, que compreende a fabricação de imagens e as operações de ruptura-reunificação. É sempre uma representação da realidade, construída por intelectuais e artistas, políticos e politicólogos, ficcionistas e jornalistas, a partir de uma determinada comunidade cultural e linguística (Lebenswelt). A fabricação dessas imagens (funcionais ao discurso e à prática política) é, pois, tarefa cotidiana. A operação simbólica marca os momentos de crise ou mudança (troca de poder), de reunificação, de coesão, de reconstrução da identidade, e articula símbolo e ação (política), nos termos da Eucaristia, uma espécie de speech act real em suas consequências (cf. Sfez, 1988:48 e 89).

2. A história da longa duração é uma das manifestações da Nova História - movimento de renovação da historiografia que nasceu na França no fim da década de vinte do século passado, tendo como fundadores Marc Bloch, Lucien Febvre e Fernand Braudel - que vai acentuar essa tendência temporal. A história das mentalidades tem sido criticada por sua excessiva abrangência, sendo, pouco a pouco, substituída pela história das representações, ou história cultural, que dá conta das singularidades de classe sociais, gêneros e faixas etárias (Chartier, 1988).

3. Jagunço ou capanga é a designação dada ao homem armado que, agregado a um chefe político ou fazendeiro, age a seu serviço para impor sua vontade.

4. Essa expressão designa o conjunto de votos controlados por pequenos chefes locais (os chamados "cabos eleitorais") que é dado a vereadores, prefeitos ou deputados em troca de benefícios pessoais ou coletivos.

5. Na República Velha, assim eram designados os atuais governadores. 


\section{REFERÊNCIAS BIBLIOGRÁFICAS}

ARAÚJO, Francisco José. (2006), Mandonismo e Cultura Política Pós-1985. Tese de doutorado em Sociologia, Unesp, Araraquara.

ARENDT, Hannah. (1987), Homens em Tempos Sombrios. São Paulo, Companhia das Letras.

BELTRÃO, Helio. (1984), Centralização e Liberdade. Rio de Janeiro, Record.

BOURDIEU, Pierre e PASSERON, Jean-Claude. (1977), Élements pour une Théorie du Système d'Enseigneiment. Paris, Minuit.

BRESSER-PEREIRA, Luís Carlos. (2001), "Do Estado Patrimonial ao Gerencial", in P. S. Pinheiro, J. Wilheim e I. Sachs (orgs.), Brasil: Um Século de Transformações. São Paulo, Companhia das Letras.

CAMPANTE, Rubens Goyatá. (2003), “O Patrimonialismo em Faoro e Weber e a Sociologia Brasileira”. DADOS, vol. 46, no 1, pp. 153-193.

CARDOSO, Fernando Henrique. (1975), Autoritarismo e Democratização. Rio de Janeiro, Paz e Terra.

CARONE, Edgar. (1971), "Coronelismo: Definição Histórica e Bibliografia". Revista de Administração de Empresas, vol. 11, no 3, pp. 85-92.

CARVALHO, José Murilo de. (1987), Os Bestializados. São Paulo, Companhia das Letras. . (1996), “Cidadania: Tipos e Percursos”. Estudos Históricos, n으 18, pp. 337-345.

. (1997), “Mandonismo, Coronelismo, Clientelismo: Uma Discussão Conceitual”. DADOS, vol. 40, no 2. Disponível em http:/ / www.scielo.br/scielo.php? script=sci_ arttext\&pid=S0011-52581997000200003\&lng=en\&nrm=iso.

et alii. (1998), Lei, Justiça e Cidadania: Cor, Religião, Acesso a Informações e Serviços. Rio de Janeiro, CPDOC.

CHARTIER, Roger. A História Cultural: Entre Práticas e Representações. Lisboa, Difel.

DAMATTA, Roberto. (1980), Carnavais, Malandros e Heróis: Para uma Sociologia do Dilema Brasileiro. Rio de Janeiro, Zahar.

DURKHEIM, Émile. (1991), De la Division du Travail Social. Paris, PUF.

FAORO, Raymundo. (2001), Os Donos do Poder. São Paulo, Globo.

GUALBERTO, João. (1995), A Invenção do Coronel. Vitória, Águia Branca.

LEAL, Victor Nunes. (1997), Coronelismo, Enxada e Voto: O Município e o Regime Representativo no Brasil. Rio de Janeiro, Nova Fronteira.

LUSTOSA DA COSTA, Frederico e CAVALCANTI, Bianor Scelza (1991), "Mudança Organizacional no Setor Público“. Revista de Administração Pública, vol. 25, no 1, pp. $82-106$.

MOTTA, Paulo Roberto. (1987), "Modernização Administrativa: Propostas Alternativas para o Estado Latino-Americano". Revista de Administração Pública, ano 21, no 4, pp. 31-61. 
MOZZICAFREDDO, Juan. (2001), "Cidadania e Administração em Portugal", in J. Mozzicafreddo e J. S. Gomes (orgs.), Administração e Política. Oeiras, Celta.

NUNES, Edson. (1997), A Gramática Política do Brasil. Rio de Janeiro, Zahar/ENAPE.

O'DONNELL, Guillermo. (1991), "Democracia Delegativa?" Novos Estudos CEBRAP, $\mathrm{n}$ 음 31 , pp. $25-40$.

OFFE, Claus. (1984), Problemas Estruturais do Estado Capitalista. Rio de Janeiro, Tempo Brasileiro.

PAIM, Antonio. (1978), A Querela do Estatismo. Rio de Janeiro, Tempo Brasileiro.

PANG, Eul-Soo. (1979), Coronelismo e Oligarquias - 1989-1945. Rio de Janeiro, Civilização Brasileira.

PINHO, José Antônio Gomes de. (1998), “Reforma do Aparelho do Estado: Limites do Gerencialismo frente ao Patrimonialismo". Organização \& Sociedade, ano 5, vol. 12, pp. 59-79.

QUEIROZ, Maria Isaura Pereira de. (1976), O Mandonismo Local na Vida Política Brasileira e Outros Ensaios. São Paulo, Alfa-Ômega.

RAMOS, Alberto Guerreiro. (1983), Administração e Contexto Brasileiro. Rio de Janeiro, Editora FGV.

RIGGS, Fred W. (1964), A Ecologia da Administração Pública. Rio de Janeiro, Editora FGV. . (1968), Administração nos Países em Desenvolvimento. Rio de Janeiro, Editora FGV.

SANTOS, Wanderley Guilherme dos. (1993), As Razões da Desordem. Rio de Janeiro, Rocco.

SCHWARTZMAN, Simon. (1988), As Bases do Autoritarismo Brasileiro. Rio de Janeiro, Campus.

SFEZ, Lucien. (1988), La Symbolique Politique. Paris, PUF (Collection Que Sais-Je?).

SOUSA, João Morais de. (1995), Coronelismo em Malta: Práticas Utilizadas para o Controle do Poder Local - 1953-1992. Dissertação de mestrado em Ciência Política, Universidade Federal de Pernambuco, Recife.

SOUZA, Jessé. (2000), A Modernização Seletiva: Uma Interpretação do Dilema Brasileiro. Brasília, Ed. UnB.

TÖNNIES, Ferdinand. (1947), Comunidad y Sociedad. Buenos Aires, Losada.

VIEIRA, Clóvis Abreu, LUSTOSA DA COSTA, Frederico e BARBOSA, Lázaro André de Oliveira. (1982), "O Jeitinho Brasileiro como um Recurso de Poder". Revista de Administração Pública, ano 16, n으 2, pp. 5-31.

VILAÇA, Marcos Vinícios e ALBUQUERQUE, Roberto Cavalcanti de. (1965), Coronel, Coronéis. Rio de Janeiro, Tempo Brasileiro.

WEBER, Max. (1994), Economia e Sociedade. Brasília, Ed. UnB, vols. I e II. 


\section{ABSTRACT \\ Relations Between State and Society in Brazil: Representations for Use by Reformers}

The main analysts of Brazilian reality have highlighted that the roots of our underdevelopment are planted in the country's historical formation, generating a series of determinants that condition the political system, the state, and its relations with society and the economy. These peculiarities constitute ways of being, proceeding, or thinking that characterize our institutions, social relations, and representations of the social and political world. Patrimonialism, abuse of authority, and personalism are examples of the "diseases" used to describe aspects of Brazilian reality that purportedly constitute the causes of limited effectiveness in government action. The analysis allows characterizing these phenomena as structure and function, indicating their influence on social, political, and administrative practices and evaluating their impact on the state's functioning and reform strategies. These categories inform the intellectual attitudes, diagnoses, and proposals for changes by reformers of all conceptual and ideological latitudes.

Key words: patrimonialism; abuse of authority; personalism

\section{RÉSUMÉ}

Rapports État et Société au Brésil: Représentations à l'Usage des Réformateurs

Les grands interprètes de la réalité brésilienne font remarquer que les racines de notre sous-développement découlent de notre formation historique, engendrant une série de caractères qui commandent le système politique, l'État et ses rapports avec la société et l'économie. Ces particularités fabriquent des façons d'être, d'agir ou de penser qui définissent nos institutions, relations sociales et représentations du monde social et politique. Patrimonialisme, autoritarisme et personnalisme sont des exemples des "pathologies" utilisées pour décrire des aspects de notre réalité qui seraient les causes de la faible efficacité de l'action gouvernementale. Cette analyse permet de caractériser ces phénomènes comme structure et fonction, d'indiquer leur influence sur les pratiques sociales, politiques et administratives et d'évaluer leur impact sur le fonctionnement de l'État et ses stratégies de réforme. Ces catégories informent des attitudes intellectuelles, des diagnostics et des propositions de changements des réformateurs de toutes les latitudes conceptuelles et idéologiques.

Mots-clé: patrimonialisme; autoritarisme; personnalisme 